\title{
Incidence of Canine Hypersensitivity in the Region of North Eastern Bohemia
}

\author{
S. POČTA ${ }^{1}$, M. SVOBODA ${ }^{2}$ \\ ${ }^{1}$ Veterinary Clinic, Nové Město nad Metují, Czech Republic \\ ${ }^{2}$ Faculty of Veterinary Medicine, University of Veterinary and Pharmaceutical Sciences Brno, Czech Republic \\ Received January 31, 2007 \\ Accepted June 5, 2007
}

\begin{abstract}
Počta S., M. Svoboda: Incidence of Canine Hypersensitivity in the Region of North Eastern Bohemia. Acta Vet. Brno 2007, 76: 451-459.

The aim of the study was to determine the incidence of different types of hypersensitivity disorders in dogs in the region of North Eastern Bohemia in the period of 1994 - 2005. In total 150 dogs were included in the study based on suspected hypersensitivity reaction. The incidence of hypersensitivity disorders in the broadly selected group of patients with dermatological problems was $3.5 \%$. The most common diagnosis was atopic dermatitis ( 94 cases) followed by flea allergy dermatitis (80 cases) and food hypersensitivity (18 cases). In terms of breed predilection, the highest number of hypersensitivity cases were Boxers (100\%) and French bulldogs $(92.3 \%)$ which is significantly higher proportion $(p<0.05)$ compared to Shar-Peis $(50 \%)$ and significantly even higher proportion $(p<0.01)$ compared to other breeds. In relation to age and sex, no significant differences were observed in incidence of hypersensitivity disorders. Canine atopic dermatitis and flea allergy dermatitis were most commonly diagnosed between 6 months and 3 years of age. Sex predilection was not observed in any of the hypersensitivity reactions. Hormonal hypersensitivity was diagnosed in 4 patients over 6 years of age. Angioedema, rash and insect bite hypersensitivity was diagnosed in 8 acute cases where fast recovery was observed after institution of appropriate therapy.
\end{abstract}

Canine atopic dermatitis, food hypersensitivity, flea allergy dermatitis, hormonal hypersensitivity

Hypersensitivity reactions belong to the group of immune disorders. They represent an overreaction to allergens from the external environment produced by protective systems of the body. Incidence of hypersensitivity disorders in canine population, most frequently represented by atopic dermatitis, reaches about 10\% (Scott et al. 2001) and as in human population, further increase is expected. Ever closer contact between humans and their pets (Baranyiová et. al. 2005) means that they share common environment and are exposed to the same allergens.

Canine atopic dermatitis is usually diagnosed in patients from 6 months to 3 years of age, but its clinical signs were also observed in animals under 6 months and over 7 years of age (Nesbitt et al. 1984; Griffin 1993; Scott et al. 1995; Saridomichelakis et al. 1999).

Breed composition of canine population in a particular region and popularity of individual breeds can to some extent affect the results of breed predilection to atopic dermatitis in the examined area. Even if the disease can be confirmed in all breeds including cross-bred dogs, predilection of some breeds has been well-documented. Most susceptible breeds are West Highland White Terrier and other terriers, Boxer, Dalmatian, French Bulldog, SharPei, English and Irish setters, Schnauzer, Dachshund, Labrador Retriever, Lhasa-Apso and Yorkshire Terrier (Halliwell and Schwartzman 1971; Scott 1981; Halliwell and Gordman 1989; Carlotti and Costargent 1994; Saridomichelakis et al.1999).

Results of studies investigating sex predilection to atopy are conflicting. According to some authors there is no sex predilection for atopic dermatitis (Willemse and van den Brom 1983; Carlotti and Costargent 1994; Saridomichelakis et al. 1999), one study

Address for correspondence:

MVDr. Stanislav Počta

Nádražní 371

54901 Nové Město nad Metuji

Czech Republic

Phone: +420491472515

E-mail: stanislav.pocta@gmail.com

http://www.vfu.cz/acta-vet/actavet.htm 
observed higher incidence of the disease in male dogs (Nesbitt 1978), other studies conversely confirmed higher incidence in female dogs (Halliwell and Schwartzman 1971; Scott 1981; Nesbitt et al. 1984). Patients with atopic dermatitis also have a predilection to other forms of hypersensitivity reactions, so they often suffer from both atopic dermatitis and food hypersensitivity (Rosser 1993), or atopic dermatitis in combination with flea bite hypersensitivity (Halliwell et al. 1987).

The most frequent hypersensitivity reaction and at the same time dermatological disease of dogs is flea allergy dermatitis (Scott et al. 2001). About $40 \%$ of dogs are positive to flea allergen when skin tested and in dogs with atopic dermatitis this figure reaches up to $80 \%$ (Scott et al. 2001).

There is no breed or sex predilection for flea allergy dermatitis (Scott et al. 2001). The disease most frequently occurs in animals from 3 to 5 years of age; patients under 6 months of age are rare (Scott et al. 2001). Based on diagnostic results from 17 veterinary clinics, incidence of flea allergy dermatitis 4 times exceeded that of other allergic skin diseases (Sischo et al. 1989). On the contrary Carlotti and Costargent (1994) reported conflicting data in Europe with atopic dermatitis diagnosed in $57 \%$ of dogs, flea allergy dermatitis in $8.7 \%$ and both pathologies confirmed in $31 \%$ of examined patients.

Food hypersensitivity is the third most frequent canine hypersensitivity disorder. Its incidence is up to $5 \%$ of all dermatological patients and it represents up to $15 \%$ of all canine allergic diseases (Carlotti 1990). Other sources observed incidence at the level of 3\% (Kukle and Horner 1992), 2\% (Carlotti and Costargent 1994) and 4\% (Hillier et al. 2000) of all dermatological cases. There is no age, sex or breed predilection with food hypersensitivity (Scott et al. 1995).

Some studies noted higher incidence of food hypersensitivity in Cocker Spaniels, Springer Spaniels, Labrador Retrievers, Shar-Peis, West Highland White Terriers, Collies, Boxers, Dalmatians, German Shepherds and Golden Retrievers (Harvey 1993; Rosser 1993; Denis and Paradis 1994).

Rash and angioedema are rare conditions in dogs (Scott et al. 2001). They most frequently appear in the form of reaction to different stimuli, e.g. some medicaments, antisera and vaccines, insect bites, intestinal parasites, sunshine etc.

Insect hypersensitivity is often an acute condition manifested by rash and angioedema. Apart from fleas, acute hypersensitivity reaction can be provoked by sarcoptic mange, ticks, different types of mosquitoes, midges, black flies, horse flies, bees, wasps and ants (Rybníček et al. 2000).

Contact hypersensitivity is an uncommon disease of dogs affecting body sites with thin coat that can come in contact with allergens.

Hormonal hypersensitivity is a rare disease caused by hypersensitive reaction to sex hormones. It occurs in female dogs suffering from ovarial problems and pseudopregnancy, usually over 5 years of age (Scott et al. 2001).

Hypersensitive reactions to bacteria, yeasts and moulds are very rare and difficult to confirm.

\section{Materials and Methods}

\footnotetext{
A hundred and fifty patients with suspected hypersensitive disorder were included into our study group in the period from January 1, 1994 to December 31, 2005. Precise figures demonstrating the number of examined animals at the clinic are available since the year 2000. In the period from January 1, 2000 to December 31, 2005 a total of 5.044 dogs were treated with dermatological patients amounting to 1.735 cases, which is $34.4 \%$ of all patients. Sixty cases of patients with dermatological problems were included into the study group, i.e. $3.5 \%$ of hypersensitive dogs. The majority of them were from North Eastern Bohemia.

Patients with pruritus and skin problems (primary and secondary skin lesions) were included in the study group; possible breed, sex and age predilections were observed.

Skin scrapings were routinely performed in all pruritic patients to exclude parasitic disease. Dogs suffering from
} 
pyoderma or Malassezia dermatitis were properly treated. Other diagnostic procedures consisted of determining the presence of fleas, use of elimination diet in patients suspected of food allergy and based on facts from history given by owners also of special diagnostic tests (microscopic examination, Wood's lamp test, cytology, bacterial cultivation and blood biochemistry). Finally working diagnosis was formulated based on differential diagnostics of hypersensitivity disorders.

In dogs suspected of atopic dermatitis corticosteroid and antihistaminic treatment was stopped in case of local medication 3 weeks and systemic medication 6 - 8 weeks before allergy skin testing. For the testing we used commercially available Artuvetrin Test Set produced by Artu Biologicals, Netherlands. This set contains 13 allergen solutions and in the case of pollens, mixtures of several allergens and 2 control solutions. Flea allergen from the same producer was also routinely added to the testing panel.

Patients were fed an elimination diet in the form of commercial hypoallergenic food based on modified proteins for the period of 6 - 8 weeks. In case of decrease in pruritus by at least $50 \%$ or partial or complete resolution of clinical signs of hypersensitivity disorder, the response to diet was interpreted as positive. Then different original diets according to feeding history of the patient were used as a part of dietary challenge. Diets with suspected allergen were given for the period of 5 - 7 days. The most frequently tested allergens were milk and dairy products, beef, pork and chicken meat, cereals or soy, chocolate or fish. After each dietary challenge that provoked pruritus, elimination diet was reinstituted till complete resolution of pruritus.

The diagnosis of flea allergy dermatitis was reached based on history, detailed clinical examination with positive finding of different developmental stages of the parasite or its faeces in the patient, typical distribution of lesions and eventual positive result of the skin test with flea allergen. When suspected of combination of atopic dermatitis, food hypersensitivity and flea allergy dermatitis, the patients were treated with antiparasitics and at the same time fed an elimination diet.

Insect hypersensitivity was diagnosed according to history and clinical signs. Peracute or acute clinical signs and history were crucial for the diagnosis of urticaria and angioedema.

We did not encounter a case of contact, bacterial or mould hypersensitivity. Hormonal hypersensitivity was diagnosed based on history, clinical signs manifested as pruritus, erythema and papules and crusts located around vulva, perineum, caudomedial thighs and mammary glands in oestrus or pseudopregnancy. The pruritus tends to spread cranially and affects paws and ears. In case of male hormonal hypersensitivity with non-seasonal signs, scrotum was affected and other areas similar to dermatologic signs of female hormonal hypersensitivity. The diagnosis was based on history, physical findings and positive response to castration therapy. Intradermal allergy testing was not made.

We used Chi-squared test for statistical analysis of results in cooperation with the Veterinary Research Institute in Brno.

\section{Results}

A total of 150 hypersensitive patients were included into our study group in the period from January 1994 to December 2005. Some patients suffered from combinations of hypersensitive disorders, most frequently atopic dermatitis, food hypersensitivity plus flea allergy dermatitis.

Table 1. Distribution of hypersensitivity disorders in our study group

\begin{tabular}{|l|c|c|}
\hline \multicolumn{1}{|c|}{ Hypersensitivity disorder } & $\begin{array}{c}\text { Number of patients } \\
(\mathrm{n}=150)\end{array}$ & Percentage \\
\hline Atopic dermatitis & 94 & 62.7 \\
\hline Flea allergy dermatitis & 80 & 53.3 \\
\hline Food hypersensitivity & 18 & 12.0 \\
\hline Angioedema and urticaria & 3 & 2.0 \\
\hline Insect hypersensitivity & 5 & 3.3 \\
\hline Hormonal hypersensitivity & 4 & 2.7 \\
\hline
\end{tabular}

No differences were observed in frequency of hypersensitivity disorders among breeds. The highest number of hypersensitivity cases were Boxers $(100 \%)$ and French Bulldogs $(92.3 \%)$ which is a significantly higher proportion $(p<0.05)$ in comparison to Shar-Peis $(50 \%)$ and significantly higher proportion $(p<0.01)$ in comparison to all other breeds. On the contrary, the lowest frequency of hypersensitive reactions was determined in Yorkshire Terriers (5.4\%), Dachshunds (6\%), Poodles (7.3\%) and German Shepherds $(8.7 \%)$ which is significantly lower $(p<0.01)$ in all these breeds in comparison with Schnauzers $(21.4 \%)$, 
Dalmatians (41.7\%), Shar-Peis, French Bulldogs and Boxers. The total number of treated patients of different breeds versus hypersensitive individuals is displayed in Table 2.

Table 2. Number of hypersensitive patients of selected breeds

\begin{tabular}{|l|c|c|c|}
\hline \multicolumn{4}{|c|}{ Patients treated in the period of 1994 -2005 } \\
\hline Breed & Total number of patients & $\begin{array}{c}\text { Patients with hypersensitivity } \\
\text { disorders }\end{array}$ & $\begin{array}{c}\text { Patients with atopic } \\
\text { dermatitis }\end{array}$ \\
\hline German Shepherd & 149 & 13 & 9 \\
\hline Poodle & 123 & 9 & 4 \\
\hline Dachshund & 149 & 9 & 4 \\
\hline Yorkshire Terrier & 93 & 5 & 5 \\
\hline Shar-Pei & 12 & 6 & 8 \\
\hline Boxer & 8 & 8 & 3 \\
\hline Labrador Retriever & 38 & 5 & 1 \\
\hline Golden Retriever & 23 & 3 & 7 \\
\hline French Bulldog & 13 & 12 & 2 \\
\hline Cocker Spaniel & 54 & 9 & 5 \\
\hline Schnauzer & 28 & 6 & \\
\hline Dalmatian & 12 & 5 & 5 \\
\hline
\end{tabular}

No breed predilection to food hypersensitivity, insect hypersensitivity and hormonal hypersensitivity was observed.

Atopic dermatitis was most frequently diagnosed in patients 3.1 to 6 years old (in total 37 patients) and also in the age group 1.1 - 3 years (in total 36 patients).

Flea allergy dermatitis was confirmed with highest frequency in the age group 1.1 to 3 years (in total 28 patients) and 3.1 to 6 years (in total 27 patients).

Fifty per cent of patients ( 9 cases) with food hypersensitivity were under 3 years of age. Three dogs of the total of 4 hormonal hypersensitivity cases were over 6 years old.

The age-related incidence of hypersensitivity disorders is shown in Table 3.

Table 3. Age-related incidence of hypersensitivity disorders in dogs

\begin{tabular}{|c|r|r|r|r|r|r|r|r|r|r|r|r|}
\hline \multicolumn{10}{|c|}{ Incidence of hypersensitivity disorders in dogs } \\
\hline Age category & \multicolumn{2}{|c|}{ Atopic dermatitis } & \multicolumn{2}{c|}{$\begin{array}{c}\text { Flea allergy } \\
\text { dermatitis }\end{array}$} & \multicolumn{2}{|c|}{$\begin{array}{c}\text { Food } \\
\text { hypersensitivity }\end{array}$} & \multicolumn{2}{|c|}{$\begin{array}{c}\text { Insect } \\
\text { hypersensitivity }\end{array}$} & \multicolumn{2}{|c|}{$\begin{array}{c}\text { Hormonal } \\
\text { hypersensitivity }\end{array}$} & \multicolumn{2}{c|}{$\begin{array}{c}\text { Angioedema } \\
\text { and rash }\end{array}$} \\
\hline under 6 months & 0 & $0.00 \%$ & 4 & $5.00 \%$ & 1 & $5.56 \%$ & 0 & $0.00 \%$ & 0 & $0.00 \%$ & 1 & $33.33 \%$ \\
\hline 6 - 12 months & 10 & $10.64 \%$ & 9 & $11.25 \%$ & 4 & $22.22 \%$ & 0 & $0.00 \%$ & 0 & $0.00 \%$ & 0 & $0.00 \%$ \\
\hline 1.1 - 3 years & 36 & $38.30 \%$ & 28 & $35.00 \%$ & 4 & $22.22 \%$ & 2 & $40.00 \%$ & 0 & $0.00 \%$ & 0 & $0.00 \%$ \\
\hline 3.1 - 6 years & 37 & $39.36 \%$ & 27 & $33.75 \%$ & 6 & $33.33 \%$ & 2 & $40.00 \%$ & 1 & $25.00 \%$ & 1 & $33.33 \%$ \\
\hline over 6 years & 11 & $11.70 \%$ & 12 & $15.00 \%$ & 3 & $16.67 \%$ & 1 & $20.00 \%$ & 3 & $75.00 \%$ & 1 & $33.33 \%$ \\
\hline Total & 94 & $100.00 \%$ & 80 & $100.00 \%$ & 18 & $100.00 \%$ & 5 & $100.00 \%$ & 4 & $100.00 \%$ & 3 & $100.00 \%$ \\
\hline
\end{tabular}

No significant differences were observed in the incidence of hypersensitivity disorders related to age category as shown in Table 3.

Table 4 documents the fact that no sex predilection was confirmed for any of hypersensitivity disorders in dogs.

Distribution of hypersensitivities based on the number of cases $(n=150)$ included in the study is shown in Tables $5-7$.

Atopic dermatitis was most frequently diagnosed alone in 52 patients and in combination with flea bite hypersensitivity in 26 patients. Flea allergy dermatitis was diagnosed alone in 
Table 4. Sex-related incidence of hypersensitivity disorders in dogs

\begin{tabular}{|c|c|c|c|c|c|c|c|c|c|c|c|c|}
\hline \multicolumn{13}{|c|}{ Sex-related incidence of hypersensitivity disorders in dogs } \\
\hline Sex & \multicolumn{2}{|c|}{$\begin{array}{c}\text { Atopic dermatitis } \\
\text { dermatitis }\end{array}$} & \multicolumn{2}{|c|}{$\begin{array}{l}\text { Flea allergy } \\
\text { dermatitis }\end{array}$} & \multicolumn{2}{|c|}{$\begin{array}{c}\text { Food } \\
\text { hypersensitivity }\end{array}$} & \multicolumn{2}{|c|}{$\begin{array}{c}\text { Insect } \\
\text { hypersensitivity }\end{array}$} & \multicolumn{2}{|c|}{$\begin{array}{c}\text { Hormonal } \\
\text { hypersensitivity }\end{array}$} & \multicolumn{2}{|c|}{$\begin{array}{l}\text { Angioedema } \\
\text { and rash }\end{array}$} \\
\hline Male & 48 & $51.06 \%$ & 43 & $53.75 \%$ & 8 & $44.44 \%$ & 3 & $60.00 \%$ & 1 & $25.00 \%$ & 1 & $33.33 \%$ \\
\hline Female & 46 & $48.94 \%$ & 37 & $46.25 \%$ & 10 & $55.56 \%$ & 2 & $40.00 \%$ & 3 & $75.00 \%$ & 2 & $66.67 \%$ \\
\hline
\end{tabular}

Table 5. Incidence of Atopic Dermatitis in combination with other hypersensitivity disorders $(\mathrm{n}=94)$

\begin{tabular}{|l|c|c|}
\hline \multicolumn{1}{|c|}{ Hypersensitivity disorders and their combinations } & \multicolumn{2}{c|}{ Incidence } \\
\cline { 2 - 3 } & Cases & Per cent \\
\hline Atopic dermatitis (alone without other skin hypersensitivity disorders) & 52 & 55.32 \\
\hline Atopic dermatitis in combination with flea allergy dermatitis & 26 & 27.66 \\
\hline Atopic dermatitis in combination with food hypersensitivity & 7 & 7.45 \\
\hline Atopic dermatitis + food hypersensitivity + flea allergy dermatitis & 4 & 4.26 \\
\hline Atopic dermatitis + flea allergy dermatitis + insect hypersensitivity & 2 & 2.13 \\
\hline Atopic dermatitis + flea allergy dermatitis + angioedema & 1 & 1.06 \\
\hline Atopic dermatitis + flea allergy dermatitis + hormonal hypersensitivity & 1 & 1.06 \\
\hline Atopic dermatitis + insect hypersensitivity & 1 & 1.06 \\
\hline Total number of cases & 94 & 100.00 \\
\hline
\end{tabular}

Table 6. Incidence of flea allergy dermatitis in combination with other hypersensitivity disorders $(\mathrm{n}=80)$

\begin{tabular}{|l|c|c|}
\hline \multicolumn{1}{|c|}{ Flea allergy dermatitis } & \multicolumn{2}{c|}{ Incidence } \\
\cline { 2 - 3 } & Cases & Per cent \\
\hline Flea allergy dermatitis & 43 & 53.75 \\
\hline Flea allergy dermatitis + atopic dermatitis & 26 & 32.50 \\
\hline Flea allergy dermatitis + food hypersensitivity & 1 & 1.25 \\
\hline Flea allergy dermatitis + food hypersensitivity + atopic dermatitis & 4 & 5.00 \\
\hline Flea allergy dermatitis + atopic dermatitis + insect hypersensitivity & 2 & 2.50 \\
\hline Flea allergy dermatitis + atopic dermatitis + angioedema and rash & 1 & 1.25 \\
\hline Flea allergy dermatitis + atopic dermatitis + hormonal hypersensitivity & 1 & 1.25 \\
\hline Flea allergy dermatitis + hormonal hypersensitivity & 2 & 2.50 \\
\hline Total number of cases & 80 & 100.00 \\
\hline
\end{tabular}

43 patients whereas food hypersensitivity was most frequently diagnosed in combination with atopic dermatitis in 7 dogs and alone in 5 patients.

Insect hypersensitivity was diagnosed in 5 patients but only in one of those as a reaction to bee sting.

Hormonal hypersensitivity was confirmed in 4 patients and 3 of them were over 6 years old. Angioedema and rash appeared as a manifestation of drug reaction in 3 cases.

To finalise the diagnosis we performed a total of 69 skin tests in the period from January 1994 to December 2005. In the same period we tried to identify the food allergen in 18 patients and confirmed the diagnosis in 8 cases.

\section{Discussion}

The veterinary clinic monitored hypersensitive reactions for 12 years. A total of 150 dogs were enlisted in the selected group. From the total number of 1.735 , i.e. $34.4 \%$ of dermatological patients in the period between January 2000 and December 2005, 60 
Table 7. Incidence of food hypersensitivity in combination with other hypersensitivity disorders $(n=18)$

\begin{tabular}{|l|r|r|}
\hline \multicolumn{1}{|c|}{ Food hypersensitivity } & \multicolumn{2}{|c|}{ Incidence } \\
\cline { 2 - 3 } & Cases & \multicolumn{2}{c|}{ Per cent } \\
\hline Food hypersensitivity & 5 & 27.78 \\
\hline Food hypersensitivity + atopic dermatitis & 7 & 38.89 \\
\hline Food hypersensitivity + atopic dermatitis + flea allergy dermatitis & 4 & 22.22 \\
\hline Food hypersensitivity + insect hypersensitivity & 1 & 5.56 \\
\hline Food hypersensitivity + flea allergy dermatitis & 1 & 5.56 \\
\hline Total number of cases & 18 & 100.00 \\
\hline
\end{tabular}

patients, i.e. $3.5 \%$, were included in the monitored study group of hypersensitive patients.

The total number of hypersensitive patients was probably higher, but we must state that some patients were insufficiently diagnosed due to low occurrence of clinical symptoms or due to disappearing dermatological changes as a result of symptomatic treatment. The lack of interest on the side of the owner to further specify the diagnosis could have been influenced by the seasonal character of the disease, which led to temporary improvement in the health of the patient. Financial reasons also played their role, as well as progressive withdrawal of clinical symptoms or frequent relapses of skin problems, which either led to the loss of the client or to the loss of interest in further collaboration in diagnostics and causal therapeutic solution.

In general, real prevalence of hypersensitive reactions is difficult to determine, as some clinical symptoms are sometimes not assessed by the veterinarian or owner as a manifestation of a hypersensitive reaction (chronic otitis, bacterial or yeast infections). A reliable method of proving whether the clinical symptoms of hypersensitivity were caused by an allergen is also missing (Hillier and Griffin 2001). Incidence and prevalence of hypersensitive reactions reported by various veterinary clinics differs as well. The collected and cited data on the incidence and prevalence of hypersensitive reactions in dogs, namely atopic dermatitis, contain many errors due to the aforementioned reasons (Hillier and Griffin 2001).

Atopic dermatitis was diagnosed as the most frequent hypersensitivity in the total of 94 patients, which constitutes $62.7 \%$ of the total number of 150 dogs. In 52 patients $(34.6 \%$ cases) from the monitored study group it was diagnosed as an independent disease of allergic origin. Flea allergy dermatitis was diagnosed alone in 43 patients $(28.6 \%$ of all cases), together with atopic dermatitis or other hypersensitivity in 34 patients $(22.6 \%$ of all cases). The occurrence of flea allergy dermatitis was diagnosed together with atopic dermatitis due to positive intradermal test in $22 / 150$ patients ( $14 \%$ of all cases). By way of comparison, Carlotti and Costargent (1994) quote the incidence of flea allergy dermatitis combined with atopic dermatitis in $31 \%$ of examined dogs. It is also necessary to take into account the hypothesis that atopic dermatitis does not increase intradermal reactivity to flea allergens, or that it does not support the origination of flea allergy dermatitis, as Sousa and Halliwell (2001) suggested.

Flea allergy dermatitis is cited as the most frequent allergic disease (Scott et al. 2001). In our set of 150 patients we diagnosed more cases with atopic dermatitis, and other authors came to the same conclusion (Carlotti and Costargent 1994). The higher number of atopic patients at our department was partly influenced by references from other institutions and by the fact that the flea allergy dermatitis is successfully treated by veterinarians upon the first contact with the patient, and this is why we were seldom confronted with these cases.

Food hypersensitivity was independently diagnosed only in 5 patients $(3.3 \%$ of all hypersensitivity cases) and combined with other hypersensitivities in 13 patients $(8.6 \%$ 
of the total). Carlotti et al. (1990) quote that food hypersensitivity is the third most frequent hypersensitivity, up to $15 \%$ of all allergic diseases in dogs, but our findings do not corroborate this frequency. Our food hypersensitivity findings correspond with findings of other authors (Kukle and Horner 1992; Carlotti and Costargent 1994; Hillier et al. 2000) and it can be assumed that to achieve objective results, hypo-allergenic diet must be administered for at least $6-8$ weeks, or up to 12 weeks. The positive effect (withdrawal of pruritus and clinical symptoms) can be substantially positively affected by the action of cytokines in the patient. Cytokines are able to release histamine for a long time, even if the allergen is absent (Halliwell 1992; 1993).

According to our results, the incidence of food hypersensitivity combined with atopic dermatitis was diagnosed in 11 dogs out of 94 atopic patients (11.7\%).

A link between atopic dermatitis and food hypersensitivity probably exists, but sufficient proofs corroborating this theory were not submitted yet (Hillier and Griffin 2001).

The increased incidence of atopic dermatitis was recorded in Boxer (8 patients, i.e. $100 \%)$ and French Bulldog (12 patients, i.e. 92.3\%), which is significantly higher $(p<0.01)$ than in other breeds. The number of atopic patients was compared with the total number of treated individuals of the same breed during the monitored period. Apparently, individuals of the aforementioned breeds without health problems were presented at our clinic only rarely. The frequency of atopic dermatitis in German Shepherd (8.7\%) was assessed as very low, in spite of the higher number of atopic patients ( 8 cases). Although the literature (Halliwell and Schwartzman 1971; Scott 1981; Halliwell and Gordman 1989; Carlotti and Costargent 1994; Saridomichelakis et al. 1999) mentions similar data on breed incidence, the breed predilection is partially influenced by the composition of dog population in the area and the popularity of individual breeds.

Speculations on the hereditary and genetic predisposition to atopic dermatitis survive both in human and veterinary medical literature. Apparently, there is a genetic background, as the disease is more frequent in certain dog breeds (Sousa and Marsella 2001). Several factors related to changes of the environment in which the dogs live contribute to the increase in the incidence of atopic dermatitis. Some breeds spend most of their lives indoors where they are exposed to home dust allergens for long periods of time (Hillier and Griffin 2001). To objectively assess the real predispositions of individual dog breeds it would be helpful to monitor the development of the clinical disease in such individuals up to 6 years of age, the amount of specific $\operatorname{IgE}$ antibodies and the reactivity of intradermal allergic test (Sousa and Marsella 2001). At the same time, it is necessary to focus on the proof of genetic mutations that may be in a direct relation to the development of atopic dermatitis (Hillier and Griffin 2001).

In flea allergy dermatitis, increased incidence was recorded in mixed breeds (11 cases total) and Dachshunds ( 6 cases in total), yet there is no breed predisposition to this disease. The mutual relation with the occurrence of atopic dermatitis is supported by several hypotheses. According to one, atopic patients may be predisposed to flea allergy dermatitis (Halliwell 1986) and our results support this opinion.

In food hypersensitivity, the increased breed incidence (according to some data) relates to Cocker Spaniel, Springer Spaniel, Labrador Retriever, Shar-Pei, West Highland White Terrier, Collie, Boxer, Dalmatian, German Shepherd and Golden Retriever (Harvey 1993; Rosser 1993; Denis and Paradis 1994). We diagnosed food hypersensitivity in accordance with literature data in Shar-Pei, West Highland White Terrier, German Shepherd, Labrador and Golden Retriever.

Also in accordance with literature data (Nesbitt et al. 1984; Griffin 1993; Scott et al. 1995; Saridomichelakis et al. 1999) the age group of patients suffering from atopic dermatitis was between 6 months and 17 years. The largest age group was 3.1 - 6 years $(39.3 \%)$, but the patients from this group were often referred from other clinics with a history of long-term dermatological 
problems, so the disease in fact started at a much younger age. In the age group of 6 months to 3 years, atopic dermatitis was diagnosed in $48.9 \%$ of cases ( 46 patients in total).

Flea allergy dermatitis was most frequently diagnosed in $1.1-3$ years age group (28 patients in total) and in 3.1 - 6 years age group (27 patients in total). Scott et al. (1995) report the most frequent occurrence in the age group between 3 and 5 years and only scarce incidence in patients younger than 6 months. In our study, it was diagnosed in 4 patients younger than 6 months, but most patients ( 28 cases) were aged 1.1 - 3 years, similarly as mentioned by Nesbitt (1978). Twenty seven patients were $3.1-6$ years old. These findings suggest that the age limit for the commencement of flea allergy dermatitis is decreasing.

Food hypersensitivity was diagnosed in $50 \%$ of patients (9) under 3 years of age. Clinical symptoms at 5 months of age were found in one patient. According to medical history data, problems of some patients began before 6 months of age, but they were brought to our attention later. Occurrence of this hypersensitivity as early as at 3 months of age was mentioned by several authors (Harvey 1993; Rosser 1993; Denis and Paradis 1994).

Three patients out of four aged over 6 years suffered from hormonal hypersensitivity, which corresponds with the gradual development of clinical symptoms and the concurrent hormonal imbalance corresponding to older age. Symptoms of older animals are also mentioned by Scott et al. (1995).

Sex had no impact on the incidence of atopic dermatitis, which corresponds to published data (Willemse and van den Brom 1983; Carlotti and Costargent 1994; Saridomichelakis et al. 1999). From the total number of 94 patients, 48 individuals were male, 46 female.

Sex-related incidence of other hypersensitivities has not been proven either.

Angioedema and rash were diagnosed as hypersensitive reactions with an acute onset most frequently caused by biopreparations, insect stings and medications. Incidence was noted in eight patients regardless of sex, age or breed.

Dogs, like humans, are exposed to long-term influence of allergens in the environment, and incidence of hypersensitivity disorders, namely atopic dermatitis, can therefore be expected to further increase.

\section{Incidence hypersenzitivních reakcí u psů v regionu severovýchodních Čech}

Cílem práce bylo zjistit incidenci jednotlivých druhů hypersenzitivních reakcí u psů v oblasti severovýchodních Čech v období 1994 - 2005. Do souboru pacientů s podezřením na hypersenzitivní reakci bylo zařazeno celkem 150 psů.Ve skupině vybraných dermatologických pacienti̊ za období 2000 - 2005 byla zaznamenána incidence hypersenzitivních pacientů ve výši 3,5 \%. Nejčastěji byly diagnostikovány atopická dermatitida (94 př́padů), bleší alergická dermatitida ( 80 př́ípadů) a hypersenzitivita na krmivo (18 př́padů). U četnosti hypersenzitivity s ohledem na plemeno byly zjištěny rozdíly, nejvyšší četnost byla zjištěna u boxera $(100 \%)$ a francouzského buldočka $(92,3 \%)$, což je statisticky významně více $(p<0,05)$ než u šarpeje $(50 \%)$ a statisticky vysoce významně více $(p<0,01)$ než u ostatních plemen. Ve vztahu věku a pohlaví $\mathrm{k}$ výskytu jednotlivých hypersenzitivit nebyly zjištěny žádné statisticky významné rozdíly. Atopická dermatitida a bleší alergická dermatitida byly nejčastěji zjišsěny ve stárí 6 měsíců až 3 roky. Vliv pohlaví nebyl u žádné z hypersenzitivit zaznamenán. Hormonální hypersenzitivita byla diagnostikována u čtyř pacientů starších 6 roků. Angioedém, kopřivka a přecitlivělost na hmyzí alergeny byly diagnostikovány u 8 pacientů jako akutní stavy s rychlým ústupem klinických příznaků po zavedení odpovídající terapie.

\section{Acknowledgements}

We are grateful to RNDr. O. Matoušková for the statistical evaluation. 


\section{References}

BARANYIOVÁ E, HOLUB A, TYRLÍK M, JANÁČKOVÁ B, ERNSTOVÁ M 2005: The influence of urbanization on the behaviour of dogs in the Czech Republic. Acta Vet Brno 74: 401-409

CARLOTTI DN, REMY I, PROST C 1990: Food allergy in dogs and cats: a review of 43 cases. Vet Dermatol 1: $55-62$

CARLOTTI DN, COSTARGENT F 1994: Analyse statistique de tests cutanés positifs chez 449 chiens atteints de dermatite allergique. Prat Méd Chir Anim Comp 27: 53

DENIS S, PARADIS M 1994: L'allergie alimentaire chez le chien et le chat. II. Étude rétrospective. Méd Vét Quebec 24: 15

GRIFFIN CE 1993: Canine atopic disease. In: GRIFFIN CE, KWOCHKA K, MACDONALD J (Eds): Current Veterinary Dermatology. The Science and Art of Therapy. Mosby Year Book, St. Louis, pp. 99-120

HALLIWEL REW 1986: Flea bite hypersensitivity in dogs and cats - the current status. Tijdschr Diergeneeskd 3: $845-875$

HALLIWEL REW 1992: Comparative aspects of food intolerance. Vet Med 87: 893

HALLIWEL REW 1993: Management of dietary hypersensitivity in the dog. J Small Anim Pract 33: 156

HALLIWEL REW, GORMAN NT 1989: Atopic diseases. In: Veterinary Clinical Immunology, W. B. Saunders Comp, Philadelphia, pp. 232-252

HALLIWEL REW, SCHWARTZMAN RM 1971: Atopic disease in dog. Vet Rec 89: 209-214

HALLIWEL REW, PRESTON JF, NESBITT JG 1987: Aspects of the immunopatho-genesis of flea allergy dermatitis in dogs. Vet Immunol Immunopathol 17: 483-494

HARVEY RG 1993: Food allergy and dietary intolerance in dogs: A report of 25 cases. J. Small Anim Pract 33: 22

HILLIER A, GRIFFIN CE 2001: The ACVD task force on canine atopic dermatitis (I): incidence and prevalence. Vet Immunol Immunopathol 81: 3-4, 147-151

HILLIER A, GRIFFIN CE 2001: The ACVD task force on canine atopic dermatitis (X): is there a relationship between canine atopic dermatitis and cutaneous adverse food reactions? Vet Immunol Immunopathol 81: 227-231

HILLIER A, KWOCHKA KW, PINCHBECK LR 2000: Reactivity to intradermal injection of Dermatophagoides farinae, D. pteronyssinus house dust mite mix, and house dust in dogs suspected to have atopic dermatitis: 115 cases (1996 - 1998). J Am Vet Med Assoc 217: 536-540

KUNKLE G, HORNER S 1992: Validity of skin testing for diagnosis of food allergy in dogs. J Am Vet Med Assoc 200: 677-680

NESBITT GH 1978: Flea bite allergic dermatitis: a review and survey of 330 cases. J Am Vet Med Assoc 173: 282-288

NESBITT GH, KEDAN GS, CACIOLO P 1984: Canine atopy. Part I. Etiology and diagnosis. Comp Cont Educ Small Anim Pract 6: 73-84

ROSSER EJ JR 1993: Diagnosis of food allergy in dogs. J Am Vet Med Assoc 203: 259-262

RYBNÍČEK J SVOBODA M, SVOBODOVÁ V, RYBNIKÁŘ A, BENÁK J 2000: Nemoci kůže. In: SVOBODA M, SENIOR DF, DOUBEK J, KLIMEŠ J (Eds). Nemoci psa a kočky, 1. díl (1. vydání), ČAVLMZ - Noviko, Brno, pp. 444-462

SARIDOMICHELAKIS MN, KOUTINAS AF, GIOULEKAS D, LEONTIDIS L 1999: Canine atopic dermatitis in Greece: clinical observations and prevalence of positive intradermal test reactions in 91 spontaneous cases. Vet Immunol Immunopathol 69: 61-73

SCOTT DW 1981: Observations on canine atopy. J Am Anim Hosp Assoc 17: 91-100

SCOTT DW, MILLER JR, GRIFFIN CE 1995: Canine Atopy. In: MULLER and KIRK'S Small Animal Dermatology, $5^{\text {th }}$ ed. WB Saunders Comp, Philadephia, pp. 497-556

SCOTT DW, MILLER JR, GRIFFIN CE 2001: Skin immune system and allergic skin disease. In: MULLER and KIRK'S Small Animal Dermatology, $6^{\text {th }}$ ed. WB Saunders Comp, Philadephia, pp. 543-666

SISCHO WM, IHRKE PJ, FRANTI CE 1989: Regional distribution of 10 common skin diseases in dogs. J Am Vet Med Assoc 195: 752-756

SOUSA CA, HALLIWELL REW 2001: The ACVD task force on canine atopic dermatitis (XI): the relationship between arthropod hypersensitivity and atopic dermatitis in the dog. Vet Immunol Immunopathol 81: 233-237

SOUSA CA, MARSELLA R 2001: The ACVD task force on canine atopic dermatitis (II): genetic factors. Vet Immunol Immunopathol 81: 153-157

WILLEMSE A, VAN DEN BROM WE 1983: Investigations of the symptomatology and the significance of immediate skin test reactivity in canine atopic dermatitis. Res Vet Sci 34: 261-265 